\title{
Incorporating Culture in the Curriculum: The Concept of Probability in Nunavik Inuit Culture
}

\author{
Annie Savard, Dominic Manuel, and Terry Wan Jung Lin \\ McGill University
}

\section{Author Note}

Annie Savard, Integrated Studies in Education, McGill University; Dominic Manuel and Terry Wan Jung Lin, Research Assistants, McGill University

We want to acknowledge the collaboration with the Kativik School Board and the support grant from the Fonds de recherche société et culture du Québec (FQRSC). We want to thank Kativik School Board for their incredible support.

Address correspondence concerning this article to Annie Savard, Integrated Studies in Education, McGill University. E-mail: annie.savard@mcgill.ca

\begin{abstract}
Traditionally, Canadian Inuit have lived in the circumpolar regions of Canada and those who still live in these regions, have their own cultures, which they tend to celebrate in their educational curricula. Inuit culture reflects their traditional lifestyle, when they were nomadic, and hunted and fished to survive in incredibly difficult conditions. These cultural differences present many challenges and issues to some mathematical concepts; for instance, for Nunavik Inuit, the concept of probability has no formal definition and it does not take the same meaning as in conventional mathematics. This misalignment could cause negative effects on students' learning. Looking to bridge the gap between those two different cultural meanings, the principal investigator, Annie Savard, with the assistance of Inuit educators designed learning situations based on the traditional Inuit culture. We used an ethnomathematical model (Savard, 2008b) to frame the learning situations created. In this article, we present the learning situations created that aimed to bridge Nunavik Inuit culture and the development of probabilistic reasoning and we discuss how these learning situations supported students' mathematical understanding and cultural identity.
\end{abstract}

Keywords: Nunavik Inuit traditional culture; probability; learning situation; ethnomathematical model 


\section{Incorporating Culture in the Curriculum: The Concept of Probability in Nunavik Inuit Culture}

\section{Background}

Students learn better when mathematical tasks proposed in classrooms are authentic and meaningful (Mukhopadhyay, Powell, \& Frankenstein, 2009). It is, thus, important to consider what is meaningful and authentic for students. We believe that grounding the learning of mathematics in the culture is an effective approach. In this paper, we define culture as a social group as described by UNESCO (1982):

That in its widest sense, culture may now be said to be the whole complex of distinctive spiritual, material, intellectual and emotional features that characterize a society or social group. It includes not only the arts and letters, but also modes of life, the fundamental rights of the human being, value systems, traditions and beliefs. (UNESCO, 1982)

In our research, we found that authentic situations grounded in the sociocultural context of a group are especially important for Inuit people because of their isolation and their need to survive in their environment. Inuit in the northern part of Quebec live in an area, called Nunavik. For thousands of years, Inuit have hunted and fished in order to survive in the harsh environment, and up until the middle of the $20^{\text {th }}$ century, most Inuit were nomadic. These important conditions have contributed to shaping Inuit culture. For the Nunavik Inuit, bringing their culture into schools is far more than being able to count fish using pictures. They want to connect counting with the traditional and current ways that Inuit share fish and food as a community. Mathematics should be related to their daily lives, but not in a superficial way (Garii, Silverman, \& Barta, 2008), and should also help to motivate students to fully participate and contribute in the society (D'Ambrosio, 2001; ten Dam \& Volman, 2004). Informed by Gay (2010), we strongly believe that a culturally relevant, pedagogical goal, which meets the academic and social needs of all students, should guide the teaching of mathematics.

Since 1978, the Inuit in Nunavik have had their own school board called Kativik; they are in charge of their educational system. The curricula they created aim to recognize and celebrate their Inuit culture and prepare the younger generations for the realities of the modern world. This mission is, however, a big challenge for non-Inuit teachers, or Qallunaat as the Inuit call them, who teach at their schools because most of them are unfamiliar with Inuit culture (Berger \& Ross Epp, 2006). The language of instruction is an important issue, especially in elementary school. In fact, all subjects are taught in Inuktitut during the first three grades. Starting in Grade 4, children and their families choose another language, French or English, for their instruction (Daveluy, 2008). However, a few subjects, such as science and social studies, continue to be taught in Inuktitut language after Grade 3. The passage from a first language to a second poses a great challenge for Inuit students of Nunavik.

In addition to the language difficulty, other difficulties arise from the differences between South and North ${ }^{1}$ cultures when it comes to teaching and learning mathematics. From Grades 3 to 6, Kativik curriculum is aligned with the goals of the Quebec official curriculum (Daveluy, 2008). As Dwayne, Glanfield, and Sterenberg (2011) point out, 
there is a huge need to find ways in which Aboriginal students can have more success in mathematics. The Inuit use a base-20 numeral system, unlike the base-10 system used in the other regions of Canada (Baillargeon, Noelting, Dorais, \& Saladin D'Anglure, 1977; Poirier, 2007). The numbers have different names according to the context in which they are used. For instance, there is a different name for number three depending on whether the three objects are over, on, or under a table. The origins of the words are rooted in base-20, but only a few Inuit are able to say the numbers in Inuktitut (Baillargeon et al., 1977; Poirier, 2007). Their use has since been lost because the vocabulary of the numbers is very long and does not extend past a few hundred. Over the years, the general population started to count numbers in English.

Cultural differences create a disconnection between the mathematics taught in Nunavik schools and the daily experiences of Inuit students. This is especially true for the concept of probability. Probability is a concept that is included in the Quebec curriculum; however, the term probability in Inuktitut does not have the same meaning in English or French. In Inuktitut, a probability is translated as an estimation or a guess, which is incorrect in mathematics because in mathematics a probability can be a ratio, a frequency, or an evaluation (Briand, 2005; Konold, 1991). This may lead Nunavik Inuit students and teachers to develop different conceptual understandings of and misconceptions about the meaning of probability.

These issues and challenges led us to explore how school mathematics can be connected to Nunavik Inuit culture in a culturally responsive manner (Gay, 2010). Cultural perspective should be linked to the individual and collective needs of students and, thus, lead to mathematical enculturation (Pallascio, Allaire, Lafortune, Mongeau, \& Laquerre, 1998). To do so, we suggest that lesson development should begin with studying phenomena, artefacts, or aspects of the society and culture and then applying mathematics as another perspective to develop critical thinking. In this paper, we reveal some mathematics in Nunavik Inuit artefacts and in their traditional practices (Mukhopadhyay et al., 2009) that provide a way to make learning mathematics more meaningful for Inuit students (Sanford, Williams, Hopper, \& McGregor, 2012).

\section{Theoretical Framework}

Inspired by Mukhopadhyay and Greer (2001), Savard (2008a) developed a model in which the sociocultural context bridges the mathematical and citizenship contexts. This model suggests incorporating culture into a lesson by beginning with a sociocultural context, the study of an object from the culture, and then, moving to a mathematical context, in which mathematical concepts and procedures are used to demonstrate aspects of the culture that are being studied. Further, a citizenship context is also considered, which includes the political aspects of the society or the community and the citizenship competencies necessary to fully participate in the society (ten Dam \& Volman, 2004). The citizenship context develops critical thinking and decision-making based on the mathematical results obtained in the mathematical context by helping students to determine ways they can contribute to the community or culture and to take action.

For this paper, we linked together the learning of mathematics and Nunavik Inuit culture using Savard's (2008b) model of developing learning situations and then 
implemented these in a Grade 3 Nunavik Inuit classroom. Considering the issue of the differing conceptions of probability between Inuit students and non-Inuit teachers and Kativik curriculum, we chose to work with that concept. What we present here is part of a larger collaborative research project realized between the primary researcher and a Grade 3 classroom teacher from an Inuit school. In the following sections, we will discuss the development of probabilistic reasoning and the steps the primary researcher took in order to create the learning situations.

\section{The Development of Probabilistic Reasoning}

The concept of probability involves reasoning with the parameters of uncertainty. This uncertainty can be expressed by the possibility that an event might occur. Therefore, this concept should be developed qualitatively before quantitatively. The vocabulary is extremely important. In fact, the terms possible, impossible, and certain should be understood first and can be developed using a probability line, first without numbers, and then with numbers (Tarr, 2002). It is possible to use a physical object to find the theoretical and the frequential probabilities. A theoretical probability is a ratio and a frequential probability, also called an experiential probability, is the measurement of the frequency (Briand, 2005). In the case of theoretical probability, the use of the symmetry of the object might be used to find the equiprobability of an event (Borovcnik \& Peard, 1996). For instance, it is possible to look at a die to find the theoretical probability because the six faces are the same. Another way to find the equiprobability of an event is through experimentation, which is also a way to find a frequency, which leads to the recognition of the variability of the outcomes (Savard, 2008a). Variability (Watson \& Kelly, 2004), where there are different possible outcomes or answers, is also an important aspect of probability. These are necessary concepts to understand to live on the land. They might be used qualitatively and might not be named explicitly, but Nunavik Inuit use the reasoning behind those concepts.

From our previous research with non-Inuit students and based on the litterature review, we noted that some people from different part of the world might have other conceptions about probability. We call them alternative conceptions (Savard, 2014). For example, they might think that a spiritual force, or beliefs, or luck might control the outcome (Amir \& Williams, 1999) or that it is impossible to predict because the outcomes are random (Fischbein \& Gazit, 1984; Thibault, Lajoie, \& Savard, 2012). They might also think that the manipulation of an object influences the outcomes (Amir \& Williams, 1999; Brousseau, 2005; Watson \& Moritz, 2003). In fact, probabilistic reasoning is different from what we habitually use in reasoning. Deterministic reasoning supposes that things are determined, and relies on experiences from the past and observations in the present for an answer. Deterministic reasoning leads students to look at one definitive answer. They use a deterministic model (Shaughnessy, 1992) to represent the situation and then to give personal explanations, also called conceptions, to explain the outcome. Konold (1989) called this "personalist interpretation." For example, Amir and Williams (1999) showed that students explain the outcome of a trial by the manipulative orientation of the dice or the spinner. In many cases, students did not use probabilistic reasoning for modelling a probabilistic situation in gambling activities or learning situations (Savard, 2010). Those conceptions can create learning obstacles for people, preventing them from developing appropriate probabilistic reasoning. 
According to the Kativik School Board curriculum, probability should be taught in the early grades of elementary. Knowing that this concept is not explicitly understood in the traditional Inuit culture of that region, the Board adopted a Western view of it in its curriculum. In this case, it is the same approach as the rest of the Québec province.

\section{Learning About Traditional Nunavik Inuit Culture}

To be able to use the sociocultural context in the learning situations, the primary researcher had to become acquainted with Nunavik Inuit culture so she could find cultural activities in which probabilities would be present. To do so, she worked closely with four representatives of the Kativik School Board. These representatives (participants), between the ages of 50 and 60 years old, were familiar with ancient traditions in their culture. These relationships were beneficial, helping the researcher to experience various aspects in the day-to-day life of the community. To get a better understanding of the cultural activities in the community, the primary researcher did interviews with the participants in the study. The data consisted of a total of 19 interviews; some interviews were done with one participant and others done as group interviews with two or three participants. All interviews were audio-recorded and the primary researcher took notes in her field journal. Although this research includes only four Inuit representatives from Nunavik, it can inform educators about praxis in this particular context, and may be able to inform praxis in other similar contexts.

The interviews started with questions about the participants' views on mathematics, what the participants thought mathematical thinking represented, focusing more on probabilistic reasoning. Through the interviews, the primary researcher concluded that traditional Nunavik Inuit mathematical thinking about probability related to their environment, which placed survival at the core of their thinking. Uncertainties existed, but the Nunavik Inuit never wanted to be unsure, especially when it came to the weather. The vocabulary associated with the concept of probability in the context of the weather is slightly different, for example, impossible means either that it is not possible or that it may not be possible in Inuktitut. If they were sure, it meant that they could go out to hunt and fish. If they were not sure, they asked someone else because they needed to be sure that they could go out to hunt and fish because it affected their survival in the harsh climate. The mathematical thinking in the culture about probability does not refer to any quantity, but to a qualitative idea only. Therefore, the concept of probability is present in traditional Nunavik Inuit culture, and we felt that it needed to be explicitly linked with the curriculum.

The primary researcher questioned the participants about their traditional legends and games. She was introduced to some games that the older generations played many years ago, such as card games and a traditional dice game played while fishing. Many traditional games were based on seal bones. Seals are important in Inuit culture. They are the main food source. The Nunavik Inuit used seal skin for clothing and seal fat for fuel in stone lamps. Thus, it is understandable that Inuit people based many traditional games on the seal bones and their use.

A popular traditional game mentioned by the participants was Inugait, a game that used small seal bones taken from seal flippers or sometimes their tails. A bag or a mitten 
made from the bladder of the seal held the bones. Each bone piece had a name and represented an animal, an object, or a human. By using a slipknot, the players tried to fish the bones out of the bag with the goal of capturing the bone that represented a seal because of its importance in their culture. With the captured bones, players build a traditional camp with a food storage area and people standing guard. The camp represented the Inuit living in the traditional ways in order to survive in the North. The players then tried to steal each other's stored up food by taking turns throwing a bone like a die. When the bone landed face down, the player lost and the winner stole a bone from the opponent. The game ended when a player ran out of bones. Figure 1 shows an example of a camp constructed with seal bones.

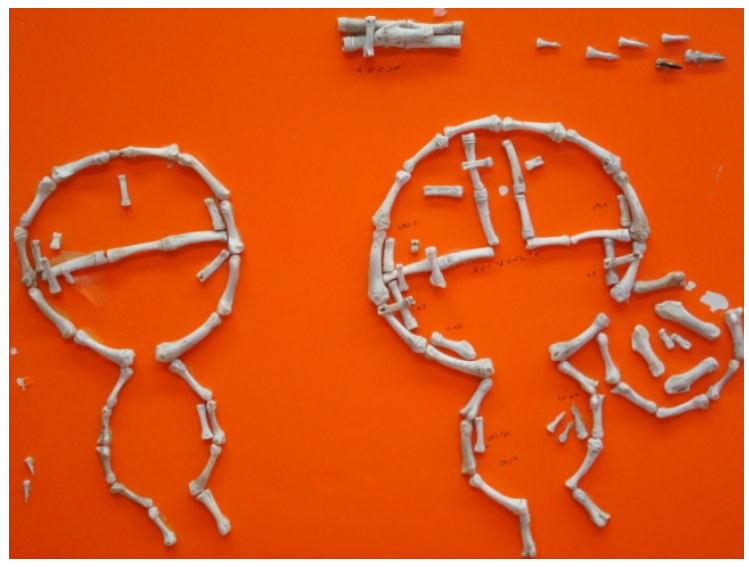

Figure 1. Example of a camp built with seal bones during the course of the Inugait game.

Another game that Nunavik Inuit people played was the Wishing Bones game. This one started with a song sung by children when the men were hunting. It has always been hard to survive in the North, especially during the winter. This traditional Inuit song sheds some light on those difficult times when people did not eat enough to survive during the cold season. The song expressed a hope for favourable weather and a chance for finding animals in order to get food. To play the game, the player placed a seal bone on his or her forehead and then sang the song. The player then made a wish and threw the bone on the floor. If a part of the bone pointed upwards, the player won, meaning the player would have food that day. Otherwise, it meant that there would be no food to eat that day. The Wishing Bones game highlights the difficult times and the traditional young Inuit's wish for getting food.

After examining the Inugait and Wishing Bones games closely, we were able to create a sequence of four learning situations that focus on using the bones with the goal of developing probabilistic reasoning in Nunavik Inuit students. We present these four learning situations in the next section. For each of them, we identify the mathematical content on probabilistic reasoning based on the traditional cultures, which bridges the sociocultural and the mathematical contexts. 


\section{Learning Situations}

The sequence of the learning situations starts with the Inugait game because it introduces the bones that will be used in most learning situations. In order to play this game, students need to know the names and the roles of the bones in the game. In the process of learning the names, they learn about their traditional culture. In fact, the names given to the bones represent their traditional community as nomads. This important work, not in mathematics, but in Languages Arts in Inuktitut and Social Studies, has to be done before playing the game. Then, introduce the Wishing Bones game because the song is used in the Inugait learning situation. These introductory activities focus on celebrating Nunavik Inuit culture envisioned in their curricula, and they represent the sociocultural context according to Savard's (2008b) ethnomathematical model.

In the following paragraphs, we will describe in more depth the learning situations developed out of the traditional games. A Grade 3 Inuit teacher implemented these situations with her students in order to develop their understanding of specific mathematical concepts.

\section{Learning Situation 1: Inugait (see Appendix A: Inugait Learning Situation Lesson Plan)}

The starting point of the lesson is rooted in a sociocultural context, Inugait. We suggest that Elders be invited to the class in order to present the game and play it in front of the students. The Elders could explain the traditional ways through their experiences. Then, students start to learn the names of the bones and their meaning by making a chart. They can practice playing the game with bones and construct cultural models like a tent or an igloo.

Then, we add a mathematical context so the students can look at the game through a different lens. To do so, students are asked to throw different bones and to observe if the pointy end faces upward or not. This can be done in teams of two. While playing the game, students have to record in order the outcomes of ten trials.. The resulting table is a compilation of all the different bones, for example, one representing the man, one representing the dog, etcetera, and then a total of the results. Students note which bones face up, which ones do not, and how many times for each (this is part of the mathematics curriculum). After the experimentation with the bones, the teacher compiles on a poster or blackboard the outcomes from each student or team. She can then ask questions such as: Which team had more bones that faced up, or which team had fewer bones facing up? Using the class results, she can ask the students to predict which bones have a better chance of facing up and to explain why they think so. The students can use the results to support their explanation as to why the chances are better or not.

It is very important that students write down all of their work throughout the learning situation. The game results can be used later on for developing critical thinking about the influence of the shape of the bones and the frequency of their outcomes. This can bring students towards the citizenship context. Also in this game, because it is important to learn which bone represents a seal, questions could be asked about the probability of catching that particular bone. 


\section{Learning Situation 2: Wishing Bones (see Appendix B: Wishing Bones Learning Situation Lesson Plan)}

The Wishing Bones learning situation starts with a sociocultural context. The teacher introduces the game to the students and sings the song related to the game. The teacher could also explain the meaning and the context of the game through a discussion. After, the students play the game and experiment by throwing the bones. The teacher organizes a discussion around the wishes and the outcomes. This is relevant because, according to their traditions, the bone was used to predict what would happen. It is also an appropriate moment to discuss with the students about wishes for getting food and wishes for getting material objects such as video games.

After the discussion about the wishes and the outcomes, the teacher will orient the discussion toward the mathematical context by asking, "Could we determine if the bones have a better chance of facing up or not?" In order to answer this question, the teacher asks students to make conjectures and then to create a small experiment to verify their conjectures. For example, each student throws a bone a certain number of times, writes their results, and compiles the total. Afterwards, the teacher points out the differences between the results and the predictions.

It is important that students write down all of their work throughout the learning situation. During the discussion, students can evaluate their wishes and the probability that the bone faces up. A citizenship context can emerge from the discussion on their wishes, why they want them to come true, and how their wishes affect the community.

\section{Learning Situation 3: Sauniit (see Appendix C: Sauniit Learning Situation Lesson Plan)}

The Sauniit learning situation builds on the sociocultural context that the Inugait learning situation created by using the same bones. First, the teacher reviews the song that was taught during the Wishing Bones learning situation and then reviews the names of the bones that students learned, using the chart created in the Inugait learning situation. The teacher asks students to draw a bone from the mitten and say the name of it. The teacher might ask students to describe the context in which these games were originally played.

Moving to the mathematical context, the teacher places some cards containing pictures of the different bones in a mitten. She then asks the students to make a prediction about which bone card has a better chance to be drawn. Each student can be asked to share their predictions with the rest of the class and to explain why they think that their choice has a better chance to be drawn out. Just like in the Wishing Bones learning situation, the students can then do an experiment, but in larger groups where each student can pull out one bone card, name the bone, and put a tally on the frequency table previously drawn on the blackboard. For this experiment, it is important that each student put the bone card back in the mitten before the next one takes his or her turn. After two turns for each student, the teacher asks the students to tally each bone card drawn. For this learning situation, because the bones are represented on a card, students are able to realize that the shape of the bones does not affect the results. Each card has the same chance of being drawn from the mitten. To make sure the students understand the concept 
of equiprobability, the teacher can put five different bone cards in the mitten and ask the students if one card has a better chance of being pulled out and, if so, why? After a discussion, students should be able to conclude that they have the same probability in theory ( 1 chance out of 5 to be drawn). Afterwards, the teacher asks the students to repeat the same experiment as the initial one, but in larger groups and with a different number of trials for each student, (e.g. 10 trials, 100 trials, etc.). Compare the results from this experimentation with the results from the initial experiment, and with the theoretical probability. It is important at this point that the teacher helps the students to realize the uncertainty of the events. In other words, although the probability might be the same, one can never exactly predict the next outcome. The teacher can also extrapolate from this by helping students understand that even if this experiment were done 1,000 times or more, the results would probably be close to the theoretical probability, but the outcomes can still never be predicted.

For the citizenship context, the teacher can launch a discussion on different games or activities with which students might be familiar or aware of, such as poker or bingo, in order to see how students will respond in those situations, given their understanding of probability. The goal here is for students to realize that even though they have a good chance to win at a bingo game, they can still lose. The discussion might also highlight how uncertainty is present in many aspects of their everyday lives and in their various activities, for example, raffles to raise money.

\section{Learning Situation 4: Makitaguk (see Appendix D: Makitaguk Learning Situation Lesson Plan)}

The sociocultural context of the Makitaguk learning situation draws on learning from discussions about the traditional way of living in the Inugait and Sauniit learning situations. While fishing, Nunavik Inuit people played a dice game. According to the tradition, one player picked a number and the other tried to get it by rolling the die one time. If the number is rolled, the player won. The teacher brings a die to class and ask students about its sides. The teacher asks about when and why students would use a die. Afterwards, the teacher can let the students play with the die, just as their Elders did traditionally.

The teacher, then, guides the students toward the mathematical context. She or he can create a six-column table with the numbers from one to six placed in each cell of the top row. Then, the whole class could experiment to discover how many times they will get each number from 1 to 6 out of 10 tries. For example, they might get a one 3 times out of 10 tries. After, they can do another 10 trials to see how many times they roll a 2 and so on. This exercise should help students see the variability for each number by noticing that even though they try the same amount of trials to get each number, they always get a different result. The teacher asks the students if some numbers occurred more often compared to the others, and if so, why they think it happened that way. This step is important so the teacher can make explicit students' thinking about the phenomenon. For example, students might say that it depends on how one throws the die. In such a case, the teacher helps them to realize that the sides are congruent, so the likelihood of getting any number is supposed to be the same. The teacher could ask questions to see if the students will conclude that all the possible results are equiprobable. 
Lastly, students can do an experiment in groups of two. They throw the dice 100 times and record the outcomes for each of them on a table. On the sheet, they write in Inuktitut the number below the digit and, on the last line, they total the outcomes, which the teacher compiles on the blackboard. By comparing the results, students have to come up with the uncertainty, because even if the probabilities to get a number on the die are the same, they still do not know what the next outcomes are going to be. Throughout the lesson, students should write all of their work on the sheet provided.

In Table 1, we present a summary of each learning situation and the mathematical content on probabilistic reasoning that is explored in each one. These learning situations develop the mathematical context according to Savard's (2008b) model. We have named the learning situations according to the traditional game it was based on.

Table 1

Description of the Four Learning Situations and Their Mathematical Content

\begin{tabular}{|c|c|c|}
\hline $\begin{array}{l}\text { Traditional } \\
\text { Game }\end{array}$ & $\begin{array}{c}\text { The Learning Situations Based on } \\
\text { Traditional Games }\end{array}$ & $\begin{array}{l}\text { Mathematical Content on } \\
\text { Probabilistic Reasoning }\end{array}$ \\
\hline Inugait & $\begin{array}{l}\text { Many different small seal bones are } \\
\text { put in a mitten (around 20). A player } \\
\text { has to catch a bone using a string with } \\
\text { a slip knot. The goal of the game is to } \\
\text { catch the bone that represents a seal, } \\
\text { because this means that people will } \\
\text { get food. The introduction of the } \\
\text { bones and learning their names is } \\
\text { done before the work on probability. }\end{array}$ & $\begin{array}{l}\text { Students consider the influence } \\
\text { of the shape of the bones and } \\
\text { their frequency. } \\
\text { The number of bones is not } \\
\text { equiprobable. }\end{array}$ \\
\hline $\begin{array}{l}\text { Wishing } \\
\text { Bones }\end{array}$ & $\begin{array}{l}\text { The player puts a bigger seal bone on } \\
\text { his forehead and sings a song. After } \\
\text { that, he makes a wish and then throws } \\
\text { the bone. If the bone stands up, he } \\
\text { wins and he will have food } \\
\text { (according to their culture). } \\
\text { Otherwise, he loses and he is not } \\
\text { going to eat today }\end{array}$ & $\begin{array}{l}\text { Students consider the frequency } \\
\text { and the manipulation of the } \\
\text { bones (deterministic conceptions } \\
\text { about the manipulation of an } \\
\text { object). Thinking about } \\
\text { uncertainty and variability of the } \\
\text { results are the main focuses in } \\
\text { this activity. }\end{array}$ \\
\hline Sauniit & $\begin{array}{l}\text { The seal bones are represented on } \\
\text { cards. The player has to throw one } \\
\text { card out of the mitten without using } \\
\text { the string, tells the name of the bone } \\
\text { and puts a tally on a table on the } \\
\text { blackboard. The player puts the bone } \\
\text { cards in the mitten and the next } \\
\text { player does the same thing. }\end{array}$ & $\begin{array}{l}\text { Students consider the } \\
\text { equiprobability of the cards. } \\
\text { They will have to determine the } \\
\text { frequency and then compare with } \\
\text { the theoretical probability. This } \\
\text { activity also leads to the passage } \\
\text { from a qualitative probability to } \\
\text { a quantitative one. }\end{array}$ \\
\hline
\end{tabular}




\begin{tabular}{|l|l|l|}
\hline Makitaguq & $\begin{array}{l}\text { Players play a game the same way } \\
\text { that the Elders did: someone picks up } \\
\text { a number between 1 and 6, and he has } \\
\text { to throw a die one time. }\end{array}$ & $\begin{array}{l}\text { Students consider the } \\
\text { equiprobability of the numbers } \\
\text { on the die. They will have to } \\
\text { evaluate the frequency and then } \\
\text { compare with the theoretical } \\
\text { probability. They will think } \\
\text { about manipulation of the die } \\
\text { (deterministic conceptions about } \\
\text { the manipulation of an object). } \\
\text { Thinking about uncertainty and } \\
\text { variability of the results are also } \\
\text { focussed. Just like Sauniit, this } \\
\text { activity also leads to the passage } \\
\text { from a qualitative probability to } \\
\text { a quantitative one. }\end{array}$ \\
\end{tabular}

\section{Discussion and Conclusion}

In the learning situations presented in this article, we were able to respect UNESCO's (1982) definition of culture by bringing the modes of life of Nunavik Inuit people inside the classroom and then by using those in order to develop probabilistic reasoning in students' mathematics. To make this bridge between the sociocultural context and the mathematical content present in the Inuit curriculum, we used Savard's (2008b) ethnomathematics model because it helped us create learning situations that could potentially lead students toward a conceptual understanding of the concept of probability. As the Inugait learning situation demonstrated, we started with the sociocultural, and then linked the mathematical context, which led students to think about a citizenship context, and to develop critical thinking. The use of this model allows us to think that it can be used in different cultural communities to build mathematical situations in regard to probability or other mathematical concepts. The learning situations developed might inform praxis in similar context and might inspire others to build mathematical learning situations on sociocultural context.

The sequence of the learning situations developed also seems to respect the development of probabilistic reasoning presented. Through the questions asked by the teacher in all the four learning situations, students can learn and use the different vocabulary concepts associated with learning probability. Students can use qualitative terms such as possible, impossible, most likely to, etc. Also, in the first two learning situations (Inugait and Wishing Bones), students can explore their different conceptions and alternate conceptions about probability with contexts where the events are not equiprobable and then move on to Sauniit and Makitaguq where they can verify whether their conceptions were still true and make comparisons of the probabilities between equiprobable and non equiprobable events. The last learning situation, Makitaguq, synthesizes all the notions learned in the previous learning situations and adds an inquirybased approach by having students create experimentations in order to verify their conjectures. The last two learning situations (Sauniit and Makitaguq) lead students 
toward a quantitative view of probability by introducing the concept of theoretical probability. For instance, in the Makitaguq learning situation, students can discover that the probability of obtaining a one by rolling a six-sided die is 1 in 6 .

We were able to conclude from the interviews with four Nunavik Inuit participants that qualitative probability is present and used in Inuit culture through their games. However, this mathematical reasoning is not extended to the use of numbers to represent probabilities, which is required in the school curriculum. Therefore, we think that the sequence of activities presented can potentially help students develop their understanding from a qualitative probabilistic reasoning towards a quantitative one, especially in the last two activities: Sauniit and Makitaguq learning situations. However, more research is needed in order to determine if that particular development of probabilistic reasoning actually occurs during the implementation of the learning activities. The next phase of this research is to study the mathematical context of these learning situations by looking closer at students' probabilistic reasoning within the learning situations that we developed and presented in this article.

A volunteer Inuit teacher and research participant implemented the four learning situations in a Grade 3 Nunavik Inuit classroom. From the interviews with this teacher, we found that the four learning situations had an impact on the students and the community. The fact that these activities presented in the classroom had such an impact in the students' lives as well as in the community is a possible sign of the richness of the learning situations that we developed, especially for the sociocultural context. These learning situations do celebrate the Inuit culture, which is the intent in the curricula. In all cases, the context of the games reflects the traditional society and the social organization of the community, past and present. Inuit are still hunting and fishing; their economy and their ways of living are oriented toward those important activities. Survival is still important in their environment and the community wants their younger generations to be prepared to live in that environment. 


\section{References}

Amir, G. S., \& Williams, J. S. (1999). Cultural influences on children's probabilistic thinking. Journal of Mathematical Behavior, 18(1), 85-107.

Baillargeon, R., Noelting, G., Dorais, L.-J., \& Saladin D'Anglure, B. (1977). Aspects sémantiques et structuraux de la numération chez les Inuit [Sematical and structural aspects of numeracy among Inuit]. Études Inuit Studies, 1(1), 93-127.

Berger, P., \& Ross Epp, J. (2006). Practices against culture that "work" in Nunavut schools: Problematizing two common practices. McGill Journal of Education, 41(1), 9-27.

Borovcnik, M., \& Peard, R. (1996). Probability. In A. J. Bishop, K. Clements, C. Keitel, J. Kilpatrick, \& C. Laborde (Eds.), International handbook of mathematical education (Vol. 2, pp. 239-287). Dordrecht: Kluwer Academic Publishers.

Briand, J. (2005). Une expérience statistique et une première approche des lois du hasard au lycée par une confrontation avec une machine simple [A statistical expermiment and a first approach of laws of chance in high school by confronting students with a simple device]. Recherches en Didactique des Mathématiques [Research in Mathematics Education ], 25(2), 247-281.

Brousseau, G. (2005). Situations fondamentales et processus génétiques de la statistique. [Fundamental situations and genetic process of statistics]. In A. Mercier \& C. Margolinas (Eds.), Balises pour la didactique des mathématiques ( 165-194). Grenoble: La pensée sauvage.

D'Ambrosio, U. (2001). What is ethnomathematics, and how can it help children in school? Teaching Children Mathematics, 7(6), 308-310.

Daveluy, M. (2008). Le français et la scolarisation des Inuit du Nunavik (Canada)[French language and schooling of Inuit from Nunavik ]. In P. Dalley \& S. Roy (Eds.), Francophonie. Minorités et pédagogies (pp. 95-119). Ottawa, ON: Presses de l'Université d'Ottawa.

Dwayne, D., Glanfield, F., \& Sterenberg, G. (2011). Culturally relational education in and with an Indigenous community. in education, 17(3), 1-7.

Fischbein, E., \& Gazit, A. (1984). Does the teaching of probability improve probabilistic intuitions? Educational Studies in Mathematics, 15, 1-24.

Garii, B., Silverman, F. L., \& Barta, J. (2008, July 2008). Crossing borders. Visualizing school mathematics outside the classroom walls. Paper presented at the The Role of Ethnomathematics in Mathematics Education International Congress on Mathematics Education (ICME 11), Monterrey, Mexico.

Gay, G. (2010). Culturally responsive teaching. Theory, research and practice. New York: Teachers College Press. 
Konold, C. (1989). Informal conceptions of probability. Cognition and Instruction, 6(1), 59-98.

Konold, C. (1991). Understanding student's beliefs about probability. In E. V. Glasersfeld (Ed.), Radical constructivism in mathematics education (pp. 139-156). Dordrecht: Kluwer academic publishers.

Mukhopadhyay, S., \& Greer, B. (2001). Modeling with purpose: Mathematics as a critical tool. In B. Atweh, H. Forgasz, \& B. Nebres (Eds.), Sociocultural research on mathematics education: An international perspective (pp. 295-311). Mahwah, NJ: Lawrence Erlbaum Associates.

Mukhopadhyay, S., Powell, A. P., \& Frankenstein, M. (2009). An ethnomathematical perspective on culturally responsive mathematics education. In S. M. Brian Greer, A. B. Powell, \& S. Nelson-Barber (Ed.), Culturally responsive mathematics education (pp. 65-84). New York, NY: Taylor \& Francis.

Pallascio, R., Allaire, R., Lafortune, L., Mongeau, P., \& Laquerre, J. (1998). Vers une activité mathématique Inuit [Toward a mathematical Inuit activity ]. Études / Inuit / Studies, 22(2), 117-135.

Poirier, L. (2007). Teaching mathematics and the Inuit community. Canadian Journal of Science, Mathematics and Technology Education, 7(1), 53-67.

Sanford, K., Williams, L., Hopper, T., \& McGregor, C. (2012). Indigenous principles informing teacher education: What we have learned. in education, 18(2), 1-9.

Savard, A. (2008a). From "real life" to mathematics: A way for improving mathematical learning. Paper presented at the International Congress on Mathematical Education (ICME 11), Monterrey, Mexico.

Savard, A. (2008b). Le développement d'une pensée critique envers les jeux de hasard et d'argent par l'enseignement des probabilités à l'école primaire: Vers une prise de décision. [The developpment of critical thinking about gambling by teaching probability at elementary school: Toward decision making]. Unpublished thesis. Université Laval, Québec.

Savard, A. (2010, July 5-9). Simulating the risk without gambling: Can student conceptions generate critical thinking about probability?. Paper presented at the International Conference on Teaching Statistic (ICOTS 8), Ljubljana, Slovenia.

Savard, A. (2014). Developing probabilistic thinking: What about people's conceptions? In E. Chernoff \& B. Sriraman (Eds.), Probabilistic thinking: Presenting plural perspectives. (Vol. 2, pp. 283-298). New York, NY: Springer Science and Business Media.

Shaughnessy, J. M. (1992). Research in probability and statistics: Reflections and directions. In D. A. Grouws (Ed.), Handbook of research on mathematics teaching and learning (pp. 465-495). New York, NY: Macmillan Publishing Company. 
Tarr, J. E. (2002). Providing opportunities to learn probability concepts. Teaching Children Mathematics, 8(8), 482-487.

ten Dam, G., \& Volman, M. (2004). Critical thinking as a citizenship competence: Teaching strategies. Learning and Instruction, 14(4), 359-379.

Thibault, M., Lajoie, C., \& Savard, A. (2012). Un processus parsemé de choix déterminants: les dessous d'un cadre conceptuel au centre d'un projet de maîtrise portant sur des conceptions d'élèves autour du hasard et des probabilités[A process determined by importants choices: underneath the theoretical framework used in a master thesis on students'conception on chance and probabilities ]. Paper presented at the Colloque sur la formation à la recherche en didactique des mathématiques [ Colloque on Training in research in Mathematics Education], Montréal.

UNESCO (1982). Mexico City declaration on cultural policies. Mexico City.

Watson, J. M., \& Kelly, B. A. (2004). Expectation versus variation: Student's decision making in a chance environment. Canadian Journal of Science, Mathematics and Technology Education, 4(3), 371-396.

Watson, J. M., \& Moritz, J. B. (2003). Fairness of dice: A longitudinal study of students' beliefs and strategies for making judgements. Journal for Research in Mathematics Education, 34(4), 270.

\section{Endnote}

${ }^{1}$ The Inuit we worked with called South the place where Qallunaat are from and the North, the place Inuit are living. 


\section{Appendix A}

\section{Inugait Learning Situation Lesson Plan}

Material:

- Inugait (seal bones, string, bag)

- Cultural model of a tent or a igloo

- Chart with the names of the bones

- Student booklet

Time:

- The introduction of the game can be done in several periods

- The mathematical part can be done in 2 periods of 30 minutes

\begin{tabular}{|c|c|}
\hline $\begin{array}{l}\text { Introduction: } \\
\text { (Culture and } \\
\text { Language) } \\
\text { Engage }\end{array}$ & $\begin{array}{l}\text { Inugait } \\
\text { Elders can present the game and play it in front of the students. They } \\
\text { can explain the traditions about how they lived in the past (Culture } \\
\text { and History). Students learn the name of the bones and their meaning } \\
\text { by making a bones chart with the teacher (Culture and Language } \\
\text { Arts:. These activities are part of social studies and language } \\
\text { programs.)Students play a game with bones and make a cultural } \\
\text { model (Tent or igloo). }\end{array}$ \\
\hline $\begin{array}{l}\text { Realization: } \\
\text { (Math: } 30 \mathrm{~min} \text { ) } \\
\text { Explore }\end{array}$ & $\begin{array}{l}\text { Students play by throwing the bones (noting how many bones are } \\
\text { facing up and not facing up). Students play in teams of two and do } 10 \\
\text { trials. They throw all the bones at the same time to record the } \\
\text { outcomes in order for each bone. At the end, they write the total of } \\
\text { bones facing up. (How many bones face up and how many do not) } \\
\text { (Mathematics program). The teacher writes the outcomes on a poster } \\
\text { (the number of bones facing up, called "stand ups" and the number of } \\
\text { bones not facing up) for each team. The teacher asks which bone has } \\
\text { more stand ups? Which one has less stand ups? The teacher asks } \\
\text { students to tell why they think this is the case. }\end{array}$ \\
\hline $\begin{array}{l}\text { Conclusion: } \\
\text { (Math: } 30 \text { min) } \\
\text { Elaborate }\end{array}$ & $\begin{array}{l}\text { Using the poster made previously, the teacher asks which bones have } \\
\text { a better chance and why (Students look the bones and explain why the } \\
\text { chance is better or not). Students throw all bones } 10 \text { times. They } \\
\text { record their outcomes in order and then count them (how many bones } \\
\text { are stand ups and how many are not). The teacher records all the } \\
\text { outcomes on a poster. Students count them and discover which bones } \\
\text { have a better chance. }\end{array}$ \\
\hline $\begin{array}{l}\text { Evaluation: } \\
\text { Evaluate (Inside } \\
\text { the realization } \\
\text { and conclusion) }\end{array}$ & Students write all of their work in a booklet, throughout the lesson. \\
\hline
\end{tabular}




\section{Appendix B}

\section{Wishing bones Learning Situation Lesson Plan}

Material:

- Seal bones

- Cultural model of a tent or a igloo

- Chart with the names of the bones

- Student booklet

Time:

- The introduction of the song can be done in one period

- The mathematical part can be done in 2 periods of 30 minutes

\begin{tabular}{|c|c|}
\hline $\begin{array}{l}\text { Introduction: } \\
\text { (Culture and } \\
\text { Language) } \\
\text { Engage }\end{array}$ & $\begin{array}{l}\text { The teacher presents the tradition about children singing while waiting } \\
\text { for hunters. She demonstrates how they used to sing and wish. } \\
\text { Students learn the song (Lyrics can be written on a board and each } \\
\text { student can have it on a sheet). }\end{array}$ \\
\hline $\begin{array}{l}\text { Realization: } \\
\text { (Math: } 30 \mathrm{~min}) \\
\text { Explore }\end{array}$ & $\begin{array}{l}\text { (Historical context) Students sing and make wishes (animals or } \\
\text { weather) before they throw the bone. They tell the wish and write it } \\
\text { down with the outcome. Each student will use the same bone. The } \\
\text { teacher guides a plenary discussion about their wishes and their } \\
\text { outcomes. Students present their wishes and their outcomes. The } \\
\text { teacher asks, "Do you think that the outcomes were influenced by the } \\
\text { wishes or that the kinds of wishes influenced the outcomes (more } \\
\text { animals up or more weather up)? The bone is supposed to predict what } \\
\text { will happen. Do you think that the strength of the wish (your really } \\
\text { wanting something) influences the outcomes? Do you think that if you } \\
\text { know that the weather is going to be good, it will make the bone stand } \\
\text { up more often? And, can we know if the bones have a better chance to } \\
\text { go up than go down?" }\end{array}$ \\
\hline $\begin{array}{l}\text { Conclusion: } \\
\text { Elaborate }\end{array}$ & $\begin{array}{l}\text { Students try to discover, like a scientific experiment or a game (it must } \\
\text { be clear that it will not be true) how many times the bones will be up. } \\
\text { Each student throws it a certain amount of times (the total should be } \\
\text { 100). They write their results and calculate the total. The teacher will } \\
\text { point out the differences between the results. }\end{array}$ \\
\hline $\begin{array}{l}\text { Evaluation: } \\
\text { Evaluate } \\
\text { (Inside the } \\
\text { realization and } \\
\text { conclusion) }\end{array}$ & $\begin{array}{l}\text { Students will write all of their work in a booklet, throughout the } \\
\text { lesson. At the end, they can write one personal wish they have. }\end{array}$ \\
\hline
\end{tabular}




\section{Appendix C}

\section{Sauniit Learning Situation Lesson Plan}

Material:

- Inugait bone cards

- Sheet

Time:

- The lesson can be done in 2 periods of 30 minutes

\begin{tabular}{|c|c|}
\hline $\begin{array}{l}\text { Introduction: } \\
\text { (Culture and } \\
\text { Language) } \\
\text { Engage }\end{array}$ & $\begin{array}{l}\text { The teacher asks the students if they recall Inugait. She or he sings the } \\
\text { song with them and asks the students to say the name of the bones, } \\
\text { using the chart. Students come and pick a bone from the mitten } \\
\text { (without using the string) and they say the name of the bone. }\end{array}$ \\
\hline $\begin{array}{l}\text { Realization: } \\
\text { (Math: } 30 \mathrm{~min} \text { ) } \\
\text { Explore }\end{array}$ & $\begin{array}{l}\text { The teacher picks up some cards and puts them in the mitten (The } \\
\text { number of cards depends on the grade of the students, but each card } \\
\text { must represent a different bone). The teacher asks which of the bones } \\
\text { has a better chance of being thrown. Students say which one and why } \\
\text { they think this particular bone card has a better chance of being picked. } \\
\text { The teacher asks them to do an experiment in larger groups. Each } \\
\text { student throws one bone card, tells the name of the bone, and puts a } \\
\text { tally on the table on the blackboard. Each student puts the bone cards } \\
\text { back in the mitten and the next student does the same. After two turns } \\
\text { for each student, the students count the tally for each bone card. The } \\
\text { teacher guides them to the conclusion that the shape of the bones card } \\
\text { does not make a difference; each card has the same chance to be } \\
\text { picked. }\end{array}$ \\
\hline $\begin{array}{l}\text { Conclusion: } \\
\text { (Math: } 30 \mathrm{~min}) \\
\text { Elaborate }\end{array}$ & $\begin{array}{l}\text { The teacher puts five different bone cards in the mitten, and then asks } \\
\text { the students if one of the cards has more of a chance than the others } \\
\text { do, and why. After a little discussion, they have to conclude that they } \\
\text { have the same probability, in theory ( } 1 \text { out of } 5 \text { probabilities to be } \\
\text { drawn). The teacher asks the students to do an experiment in larger } \\
\text { groups. Each student has to throw one bone, tell the name of it, and put } \\
\text { a tally on another table on the blackboard. The student puts the bone in } \\
\text { the mitten and the next student does the same thing. They do } 100 \text { trials. } \\
\text { They count the total for each bone. The teacher asks them if one bone } \\
\text { occurred more than the others did. She asks them to compare with the } \\
\text { theoretical probability ( } 20 \text { out of } 100 \text { ). The teacher asks them why it is } \\
\text { different. (Answer: It is what we understood from theory and what we } \\
\text { understood from the experiment.) The teacher guides students to } \\
\text { conclude their uncertainty: Even if the probabilities are the same, we } \\
\text { still do not know the next outcomes. So, the results from students are } \\
\text { valid because it was our experiment. If we do it until } 10000 \text { times, it } \\
\text { should be close to the } 20 \% \text {. However, we never know for the next } \\
\text { outcome. This is probability. You may have big chances at Bingo, but }\end{array}$ \\
\hline
\end{tabular}




\begin{tabular}{|l|l|}
\hline & you may still lose. \\
\hline Evaluation: & $\begin{array}{l}\text { Students will have to write all of their work on the sheet provided, } \\
\text { through the lesson. } \\
\text { Evaluate } \\
\text { (Inside the } \\
\text { realization and } \\
\text { conclusion) }\end{array}$ \\
\hline
\end{tabular}




\section{Appendix D}

\section{Makitaguq Learning Situation Lesson Plan}

Material:

- Dice (one by student)

- Sheet

Time:

- The lesson can be done in 2 periods of 30 minutes

\begin{tabular}{|c|c|}
\hline $\begin{array}{l}\text { Introduction: } \\
\text { (Culture and } \\
\text { Language) } \\
\text { Engage }\end{array}$ & $\begin{array}{l}\text { The teacher presents the die to the students. She asks them when } \\
\text { they would use it and why they would use it. She explains how } \\
\text { Elders used it: someone picks up a number and other people try to } \\
\text { get it (when fishing or at Christmas time). }\end{array}$ \\
\hline $\begin{array}{l}\text { Realization: } \\
\text { (Math: } 30 \mathrm{~min})\end{array}$ & $\begin{array}{l}\text { Students play by throwing the die the same way the Elders did: One } \\
\text { student picks a number and students throw a die one time. The } \\
\text { teacher writes on the blackboard the numbers they got using a table: }\end{array}$ \\
\hline Explore & $|1| 2|3| 4|5| 6 \mid$ \\
\hline Explain & $\begin{array}{l}\text { The goal is to see how many times they will get the number chosen. } \\
\text { They do it again } 10 \text { times, using the same table on the blackboard. } \\
\text { The goal is to see the variability for each number (We tried the } \\
\text { same number of trials, but we got different answers all the time). }\end{array}$ \\
\hline $\begin{array}{l}\text { Conclusion: } \\
\text { (Math: } 30 \mathrm{~min}) \\
\text { Elaborate }\end{array}$ & $\begin{array}{l}\text { The teacher asks the students if a number occurred more than the } \\
\text { others did, and asks them why this number occurred more than the } \\
\text { others did. Students might answer that it depends on the way you } \\
\text { throw it or it depends on the object. The teacher guides them to help } \\
\text { them to recognize the each side is congruent, (the same dimension). } \\
\text { The likelihood to get any number is supposed to be the same. The } \\
\text { teacher asks if it is supposed to be the same chance to get each } \\
\text { number. She asks them to do a scientific experiment, working in } \\
\text { teams of two. They throw the die } 100 \text { times and record the } \\
\text { outcomes for each of them on a sheet provided. They write in } \\
\text { Inuktitut the number below the digit. On the last line, they write } \\
\text { down the total. The teacher asks them to write down their total on } \\
\text { another table on the blackboard. Then, she compares the answer. } \\
\text { She has to come up with the uncertainty: even if the probabilities } \\
\text { are the same, we still do not know the next outcomes. It changes all } \\
\text { the time }\end{array}$ \\
\hline $\begin{array}{l}\text { Evaluation: } \\
\text { Evaluate (Inside } \\
\text { the realization } \\
\text { and conclusion) }\end{array}$ & $\begin{array}{l}\text { Students will have to write all of their work on the sheet provided, } \\
\text { through the lesson. }\end{array}$ \\
\hline
\end{tabular}

